\title{
Internet Reporting Index of Companies Listed in the Alternative Trading System New Connect Organized by the Warsaw Stock Exchange
}

\begin{abstract}
Mateusz Mogilski*
The internet is a major means of communication in business nowadays, in all its aspects, including communication between investors and issuers. This research paper examines the extent of information disclosed by companies listed on the New Connect trading platform. This market is focused on small, dynamic companies, predominantly from new technology industries, that are trying to gain attention of investors who accept higher risk associated with supporting companies with capital in their early stages and who will reap benefits in the future, when a company moves into a major market or is sold to a strategic investor. The primary aim of the article is to create a comprehensive Internet Reporting Index (IRI) applicable to smaller companies listed in the alternative trading system in Poland. The IRI index proposed in this paper was inspired by the New Connect Issuers Code of Good Practices, which contains 22 suggested items that should be disclosed on corporate websites so that a company is considered to represent good corporate governance. The secondary aim of the article is to verify six hypotheses about IRI of 106 companies being constituents of the NCI Index. The results stemming from Pearson's correlation and non-parametric tests suggest that only association with the medical sector is correlated with the Internet Reporting Index.
\end{abstract}

Keywords: internet reporting index, disclosure index, New Connect, corporate governance, investor relations.

Submitted: 12.11 .17 | Accepted: 10.01 .18

Indeks Raportowania Internetowego spółek notowanych w alternatywnym systemie obrotu New Connect organizowanym przez Giełdę Papierów Wartościowych w Warszawie

Internet stanowi główny środek komunikacji w dzisiejszym biznesie, we wszelkich jego aspektach, $w$ tym również pomiędzy inwestorami i emitentami. W artykule zbadano zakres informacji ujawnianych przez spótki notowane na New Connect na ich stronach internetowych. Rynek New Connect adresowany jest głównie do spótek sektora nowych technologii, które zamierzaja przyciagnać inwestorów akceptujących zwiększony, w porównaniu z głównym rynkiem, poziom ryzyka $w$ zamian za korzyści, które moga uzyskać $w$ przyszłości $w$ postaci większych stóp zwrotu z inwestycji. Celem artykutu jest stworzenie wszechstronnego Indeksu Raportowania Internetowego (IRI), dostosowanego do spótek notowanych na regulowanym alternatywnym systemie obrotu New Connect. Indeks ten stworzono w oparciu o Kodeks Dobrych Praktyk spótek notowanych na New Connect, które w sekcji 3. wymieniaja 22 rodzaje informacji,

\footnotetext{
Mateusz Mogilski - PhD candidate at Kozminsky University.

Correspondence address: Akademia Leona Koźmińskiego, ul. Jagiellońska 57/59, 03-301 Warszawa; e-mail: mateusz.mogilski@alk.edu.pl.
} 
które powinny się znaleźć na stronie internetowej emitenta. W artykule zamieszczono wyniki weryfikacji sześciu hipotez. Wyniki testów korelacji Pearsona oraz testów nieparametrycznych wskazuja, że jedynie fakt przynależności do sektora medycznego jest stabo skorelowany $z$ wielkościa wskaźnika IRI. Pozostałe badane czynniki nie wykazuja statystycznej korelacji z wielkościa zaproponowanego wskaźnika IRI.

Słowa kluczowe: indeks raportowania internetowego, indeks ujawnień, New Connect, ład korporacyjny, relacje inwestorskie.

Nadesłany: 12.11.17 | Zaakceptowany do druku: 10.01.18

JEL: M49

\section{Introduction}

These days, the internet as a medium to disseminate and access content of all kinds shapes the world that we live in. Its development has also impacted how companies communicate with their stakeholders, particularly investors or prospective investors, who are seeking information for construction of their portfolios. The evolution of the internet as a medium of spread of corporate information gave rise to a new corporate reporting environment that differs from the traditional paper-based one. The internet offers the facility to provide all interested parties with information that can be used in the decision-making process immediately, globally and at a low cost.

Historically, research into the use of the internet for sharing corporate information with stakeholders in general dates back to the mid 1990s. Since that time, multiple papers have been published - first concentrating on developed economies, and subsequently switching to developing economies. Academics, in most cases, analysed voluntary disclosure practices using variables derived from agency and signalling theories. The first paper about internet financial reporting targeting Poland was published in 2011 (Czajor \& Michalak, 2011). In that work, the authors created the internet financial disclosure quality measure taking into account four characteristics of information provided on the internet websites of major Polish companies.

The primary objective of this research was to develop a comprehensive Internet Reporting Index that best describes companies that are listed on the New Connect trading platform organized by the Warsaw Stock Exchange (WSE). New Connect is a platform that was created by WSE in 2007 as a twin market to London's AIM (Alternative Investment Market) or OMX's First North, with a view to attracting investors who accept higher risk in their investment in exchange for potentially higher profits. New Connect is mainly focused on small and mid-size dynamic and developing enterprises associated with various sectors of the economy. Listed companies mostly represent new technology sectors such as IT, telecommunications, biotechnology or medical. The specific characteristics of New Connect make formal obligations and information requirements imposed on stock issuers more liberal in comparison to the main market, which makes the cost of capital cheaper for issuers. However, from investors' point of view, a reduced extent of information provided means higher risk of investment, as the level of information asymmetry is greater. To introduce a standardized framework of corporate governance, the Warsaw Stock Exchange, acting as a market organizer, produced a document called New Connect Issuers Code of Good Practice (New Connect Issuers Code of Good Practice, 2010) with a view to benefiting market participants. Section 3 of that paper focuses on the information that issuers should disclose on their corporate websites. It contains 22 pieces of information about: basic information about the company and its activities (front page), description of the company's activities, with an indication which activities contribute to overall revenues the most, description of the market on which the company operates, with an indication of the company's position on the market, curricula vitae of the members of Board of Directors and Board of Management, information about 
the relationships between the members of Board of Directors and shareholders possessing at least $5 \%$ of the votes at the Shareholders' General Meeting, corporate documents, strategic plans, published financial forecasts for the current year, with assumptions for the forecasts, shareholder structure indicating major shareholders and information about the shares available in free float, contact details of investor relations personnel, etc.

To my best knowledge, there is no similar research about the level of the internet disclosures by companies listed on the New Connect market. In her research paper, Dyczkowska (2014) created the Internet Financial Reporting Index that was based on a sample of 143 companies listed on the main market of the Warsaw Stock Exchange. The inspiration for my research was the mentioned article by Dyczkowska and the fact that New Connect might form an interesting alternative for investors who are seeking to increase their alpha when constructing their portfolios, at the expense of higher risk. This market, however, is facing bad publicity in the media due to several bankruptcies of companies listed there that failed on their bond indentures and due to generally poor liquidity of the market in question. The level of corporate information provided on the website seems to be crucial for attracting entities which deliver capital to listed companies. The Internet Reporting Index proposed in this paper acts as a measure of the extent of information that is disclosed in the sample of NCI constituents and provides the opportunity to rank them from those that share more information with stakeholders, hence minimize information asymmetry, to those that do not share information at all. This measure can be used as a kind of litmus paper to select only companies of "good quality IRI" for further analysis.

This paper comprises four sections: Introduction - where a brief outline of internet reporting and the New Connect market has been presented, Previous Research - where the analysis of internet reporting literature has been discussed with a focus on description of independent variables and economic theories establishing foundations of this research, Methodology of Research and Results - depicting the sample selection, the IRI index construction and hypothesis verification, and the
Conclusion section - consisting of a short summary of results and an indication for future research.

\section{Previous Research}

The analysis of literature on internet reporting indicates a few theories based on which the research has been conducted. Those mostly referenced were the legitimacy theory, the agency theory and the signalling theory. Among these, the agency theory and the signalling theory seem to be the fundament of a vast majority of research; therefore, this research is also grounded on them.

Legitimacy is most commonly defined as "generalized perception or assumption that the actions of an entity are desirable, proper or appropriate within some socially constructed system of norms, values, beliefs, and definitions" (Suchman, 1995).

The agency theory is a subset of financial economics that focuses on conflicts of interests between people with different interests in the same assets. It attempts to explain the relationship between principals (shareholders) and agents (managers). Principals delegate (or hire) agents to achieve specific goals. There are two main problems related to the agency theory - how to align the goals of the principal so that they are not in conflict (agency problem) and that the principal and agent reconcile different tolerances for risk (Arrow, 1971).

The signalling theory, first developed by Spence (1973) to explain the behaviours on labour markets, measures the reaction to informational asymmetry. Management have more information about companies than investors do, hence by disclosing some information, they might improve the liquidity of the company's shares, which subsequently leads to a lower cost of capital. On the other hand, some less positive information might be hidden from the public sight (Diamond \& Verrecchia, 1991). A situation common on financial markets where there is a divorce of ownership (shareholders) from control (management) creates asymmetry as agents are likely to have access to superior information in comparison to the principal. In this case, the behaviour of the agent is more difficult to observe and assess by the principal. The impact of such a situation can be mitigated by the use of voluntary disclosures that can take several 
forms: minutes of meetings with analysts, press releases, annual reports, etc. (Hanafi, Kasim, Ibrahim, \& Hancock, 2009).

The Internet Reporting Index proposed in this research is grounded on these theories in the way, it measures the extent of information disclosed on the corporate website. The higher value of IRI, the better company performance in general, in accordance with the signalling theory assumptions. A higher value of the proposed IRI means that the management discloses more information to stakeholders, minimizing the information asymmetry (which forms part of the agency theory). A linkage with the legitimacy theory is through construction of the Internet Reporting Index, which is based on norms that the Warsaw Stock Exchange suggested in the published Code of Good Practices of Companies Listed on New Connect.

Most of internet reporting studies focus on developed countries, mainly the United States (Gowthorpe \& Flynn, 1997; Orens, Aerts, \& Cormier, 2010; Kelton, 2012), the United Kingdom (Hussey \& Sowinska, 1999; Dunne, Helliar, Lymer, \& Mousa, 2013) and the European Union (Marston \& Polei, 2004). In recent years, however, there has been an observable switch of interest of internet reporting towards developing countries, including Turkey (Uyar, 2011), Poland (Dyczkowska, 2014), Egypt (Samaha, Dahawy, Abdel-Meguid, \& Abdallah, 2012; Khalil \& Maghraby, 2017), Argentina (Alali \& Romero, 2012), Iran (Ghasempour \& MdYusof, 2014), Bangladesh (Biswas \& Bala, 2015), Ghana (Appiah, Amankwah, \& Adu Asamoah, 2016).

What is observable is that factors that affect internet reporting vary across countries, markets and there is no common voice by researchers on that matter. These factors include firm attributes such as: size, profitability, liquidity, leverage, association with a certain industry, auditor type, as well as other characteristics, mainly ownership structure, association of board members with significant shareholders, etc. Probably, it is impossible to generalize the results of previous studies because of differences between countries, cultures, legal requirements and economic developments.

Among the most frequently recognized dependent variables, six have been selected for this study in order to determine whether there is a correlation between the Internet Reporting Index and size, profitability, age, association with IT sector, association with the medical sector and liquidity.

In their seminal paper, Oyelere, Laswad and Fisher (2003) concentrate on internet disclosures made by New Zealand's' companies, and examine the determinants of such reporting practices, which according to them are: company size, profitability, liquidity, industrial sector and shareholder's dispersion.

Age of the company is assumed to have a positive correlation with the Internet Reporting Index, as mature companies tend to disclose more information in order to limit the information asymmetry gap between shareholders and management, aiming to maintain the capital required for their growth. Age does not seem to be a well examined independent variable that might have an impact on the level of the IRI index in the literature.

\section{Methodology of Research and Results}

The study focuses on both financial and non-financial information disclosed on corporate websites by selected entities.

For the purpose of the research, a sample of 106 companies being constituents of the NCI Index has been randomly selected as of 24th August 2017 (the list of companies is presented in Appendix I). The data source for volume, price and EPS was Thomson Reuters Eikon, whereas the details about the companies' websites were obtained from the Warsaw Stock Exchange online service. The information about company age was collected from the National Court Register (Polish Krajowy Rejestr Sadowy - KRS).

The NCI Index consists of 200 most reliable and most liquid companies of the New Connect market and is generally an indicator of market sentiment. Given the general poor liquidity of stocks listed on New Connect, the sample of NCI index is justified for verifying research hypotheses, especially those questioning relationships between IRI and volume. This sample, representing $53 \%$ of the NCI population, provides the balance between obtaining sufficient variance for reliable statistical inferences and the resources that should be employed for input data collection. 
Firstly, based on 13 elements suggested in the Code of Good Practices of Companies Listed on New Connect, a survey examining the presence of certain information as regards internet reporting on corporate websites was developed. This survey consists of the information presented in Table 1.

Table 1. Survey about information disclosed on corporate websites

\begin{tabular}{|l|l|c|}
\hline \multicolumn{1}{|c|}{ Variable } & \multicolumn{1}{|c|}{ Definition } & Frequency \\
\hline DP3.1 (X1) & Basic information about the company and its activities. & $96 \%$ \\
\hline DP3.2 (X2) & $\begin{array}{l}\text { Extended description of the company's activities, } \\
\text { with an indication of the segment that generates the majority } \\
\text { of revenues }\end{array}$ & $82 \%$ \\
\hline DP3.3 (X3) & Description of the market on which the company operates & $54 \%$ \\
\hline DP3.4 (X4) & Curricula vitae of the members of Board of Directors & $56 \%$ \\
\hline DP3.6 (X5) & Registration documents and other corporate documents & $82 \%$ \\
\hline DP3.7 (X6) & Strategic plans & $38 \%$ \\
\hline DP3.9 (X7) & Structure of ownership & $87 \%$ \\
\hline DP 3.10 (X8) & Contact details of the person responsible for investor relations & $49 \%$ \\
\hline DP 3.11 (X9) & Management discussion and analysis & $69 \%$ \\
\hline DP 3.12 (X10) & Current and periodic reports & $82 \%$ \\
\hline DP 3.13 (X11) & Investors calendar & $41 \%$ \\
\hline DP 3.19 (X12) & Information about the authorised advisor & $38 \%$ \\
\hline DP 3.20 (X13) & Information about the market maker & $50 \%$ \\
\hline
\end{tabular}

Source: author's own work.

For this purpose, a dichotomous scoring scheme was applied whereby a disclosed item was granted the score of 1 and 0 if otherwise. The Internet Reporting Index might be presented formulaically as follows:

Internet Reporting Index (IRI)

Total number of disclosed factors

Maximal number of disclosed factors

$$
I R I=\frac{\sum_{i=1}^{m} D F_{i}}{\sum_{i=1}^{n} D F_{i}},
$$

where $m \leq n$.

The IRI value equal to or higher than 0.66 is considered to be "good reporting", between 0.33 (inclusive) and 0.66 "average reporting" and below 0.33 "poor report- ing". The Internet Reporting Index is an exogenous variable in the model and it was measured by assessing the content of each of the sampled companies' websites. It captures the extent of voluntary disclosures. The study was conducted between $1^{\text {st }}$ and $10^{\text {th }}$ September 2017 and all the sampled companies had their corporate websites accessible. The quality of the Internet Reporting Index in the sample was as follows in Table 2. 
Table 2. Internet Reporting Index score frequency

\begin{tabular}{|l|c|}
\hline \multicolumn{1}{|c|}{ IRI } & Number of companies \\
\hline Good (IRI above 0.66) & 50 \\
\hline Average (IRI between 0.33 and 0.66 & 44 \\
\hline Poor (IRI below 0.33) & 12 \\
\hline Total & 106 \\
\hline
\end{tabular}

Source: author's own work.

Among 106 sampled companies, only one had the value of IRI equal to 0 (Bit Evil SA) and four were granted the maximal value of 1 (Pharmena SA, Derma Fix Medical SA, G Energy SA and Softblue SA).

Endogenous variables in the model include profitability (EPS), size (market capitalization), age (years since being registered in the National Court Register), association with the IT sector (binary variable), association with the medical sector (binary variable) and liquidity (volume).

Secondly, in order to verify six hypotheses about IRI of 106 companies being constituents of NCI Index:

H1: There is a positive correlation between the Internet Reporting Index and profitability.

H2: There is a positive correlation between the Internet Reporting Index and the firm size.

H3: There is a positive correlation between the Internet Reporting Index and age of the company.

H4: There is a positive correlation between the Internet Reporting Index and association with the IT sector.

Table 3. Results of Pearson's correlation
H5: There is a positive correlation between the Internet Reporting Index and association with the medical sector.

H6: There is a positive correlation between the Internet Reporting Index and the volume of transactions on the stock.

The correlation between the variables was examined. Table 3 depicts Pearson's correlation between variables. These metrics suggest that only association with the medical sector is correlated (positively) with the Internet Reporting Index. The correlation of 0.228 indicates a weak correlation at the 0.05 significance level. The correlation between the Internet Reporting Index and other variables was statistically insignificant. The results stemming from Pearson's correlation were confirmed by the results of non-parametric tests (Spearman's rho correlation and Kendall's taub) with the exception that non-parametric tests indicate also significance at the 0.05 level correlation between the Internet Reporting Index and size measured through market capitalization.

\begin{tabular}{|l|l|r|r|r|r|r|r|c|}
\hline \multicolumn{2}{|c|}{} & \multicolumn{6}{|c|}{ Correlations } \\
\cline { 3 - 9 } & Volume & Medical & IT & $\begin{array}{c}\text { Mcap } \\
\text { (PLN) }\end{array}$ & $\begin{array}{c}\text { Age } \\
\text { (KRS) }\end{array}$ & $\begin{array}{c}\text { EPS } \\
\text { (PLN) }\end{array}$ & $\begin{array}{c}\text { Internet } \\
\text { Disclosure } \\
\text { Index }\end{array}$ \\
\hline \multirow{3}{*}{ Volume } & Pearson Correlation & 1 & -.049 & .013 & -.039 & -.088 & -.013 & .063 \\
\cline { 2 - 9 } & Sig. (2- tailed) & & .624 & .898 & .699 & .379 & .899 & .532 \\
\cline { 2 - 9 } & $\mathrm{N}$ & 101 & 101 & 101 & 101 & 101 & 101 & 101 \\
\hline \multirow{3}{*}{ Medical } & Pearson Correlation & -.049 & 1 & -.125 & -.030 & -.041 & -.180 & .228 \\
\cline { 2 - 9 } & Sig. (2- tailed) & .624 & & .202 & .762 & .676 & .065 & .019 \\
\cline { 2 - 9 } & $\mathrm{N}$ & 101 & 106 & 106 & 106 & 106 & 106 & 106 \\
\hline
\end{tabular}


continued Table 3

\begin{tabular}{|c|c|c|c|c|c|c|c|c|}
\hline & \multicolumn{7}{|c|}{ Correlations } \\
\hline & & Volume & Medical & IT & $\begin{array}{l}\text { Mcap } \\
\text { (PLN) }\end{array}$ & $\begin{array}{c}\text { Age } \\
(\mathrm{KRS})\end{array}$ & $\begin{array}{c}\text { EPS } \\
(\text { PLN) }\end{array}$ & $\begin{array}{c}\text { Internet } \\
\text { Disclosure } \\
\text { Index }\end{array}$ \\
\hline \multirow{3}{*}{ IT } & Pearson Correlation & .013 & -.125 & 1 & .075 & -085 & .040 & -.106 \\
\hline & Sig. $(2-$ tailed $)$ & .898 & .202 & & .447 & .387 & .687 & .278 \\
\hline & $\mathrm{N}$ & 101 & 106 & 106 & 106 & 106 & 106 & 106 \\
\hline \multirow{3}{*}{$\begin{array}{l}\text { Mcap } \\
\text { (PLN) }\end{array}$} & Pearson Correlation & -.039 & -.030 & .075 & 1 & -.003 & $.389^{* *}$ & .161 \\
\hline & Sig. $(2-$ tailed $)$ & .699 & .762 & .447 & & .974 & .000 & .100 \\
\hline & $\mathrm{N}$ & 101 & 106 & 106 & 106 & 106 & 106 & 106 \\
\hline \multirow{3}{*}{$\begin{array}{l}\text { Age } \\
\text { (KRS) }\end{array}$} & Pearson Correlation & -.088 & -.041 & -.085 & -.003 & 1 & -.027 & .033 \\
\hline & Sig. $(2-$ tailed $)$ & .379 & .676 & .387 & .974 & & .787 & .733 \\
\hline & $\mathrm{N}$ & 101 & 106 & 106 & 106 & 106 & 106 & 106 \\
\hline \multirow{3}{*}{$\begin{array}{l}\text { EPS } \\
(\mathrm{PLN})\end{array}$} & Pearson Correlation & -.013 & -.180 & .040 & $.389^{* *}$ & -.027 & 1 & -.110 \\
\hline & Sig. $(2-$ tailed $)$ & .899 & .065 & .687 & .000 & .787 & & .263 \\
\hline & $\mathrm{N}$ & 101 & 106 & 106 & 106 & 106 & 106 & 106 \\
\hline \multirow{3}{*}{$\begin{array}{l}\text { Internet } \\
\text { Disclosure } \\
\text { Index }\end{array}$} & Pearson Correlation & .063 & $.228^{*}$ & -.106 & .161 & .033 & -.110 & 1 \\
\hline & Sig. $(2-$ tailed $)$ & .532 & .019 & .278 & .100 & .733 & .263 & \\
\hline & $\mathrm{N}$ & 101 & 106 & 106 & 106 & 106 & 106 & 106 \\
\hline
\end{tabular}

*. Correlation is significant at the 0.05 level (2 - tailed).

**. Correlation is significant at the 0.01 level $(2$ - tailed $)$.

Source: author's own work.

\section{Conclusion}

The results of the research suggest that only association with the medical sector is correlated positively in the sense of Pearson's correlation with the value of the Internet Reporting Index proposed. Other dependent variables such as volume of transactions on the stock (average from 6 months), association with the IT sector, market capitalization, age of the company and earnings per share were not statistically correlated to IRI at the 0.05 significance level.

This result is confirmed by non-parametric Kendall's tau b and Spearman's correlations at the 0.05 significance level. Additionally, these two tests suggest that also market capitalization is weakly positively correlated with the Internet Reporting Index score at the same significance level.

The details of Kendall's tau b and Spearman's correlation are presented in the table 4.

Given this was initial research into this field, it is impossible to compare the results with other examinations. The results are not very conclusive observations, therefore in the future it would be necessary to utilize not only one-dimensional dichotomous scale but also to include the quality of information provided as an additional dimension and endeavour to build a statistically significant regression which might have better explanatory power than Pearson's correlation. 
Table 4. Results of non-parametric tests

\begin{tabular}{|c|c|c|c|c|c|c|c|c|c|}
\hline \multicolumn{3}{|c|}{ Correlations } & \multirow{2}{*}{$\begin{array}{c}\text { Volume } \\
1.000\end{array}$} & \multirow{2}{*}{$\begin{array}{c}\text { Medical } \\
-.028\end{array}$} & \multirow{2}{*}{$\begin{array}{l}\text { IT } \\
.115\end{array}$} & \multirow{2}{*}{$\begin{array}{c}\begin{array}{l}\text { Mcap } \\
\text { (PLN) }\end{array} \\
-.109\end{array}$} & \multirow{2}{*}{$\begin{array}{c}\begin{array}{c}\text { Age } \\
\text { (KRS) }\end{array} \\
-.001\end{array}$} & \multirow{2}{*}{$\begin{array}{c}\begin{array}{c}\text { EPS } \\
(\text { PLN) }\end{array} \\
-.195^{* *}\end{array}$} & \multirow{2}{*}{\begin{tabular}{|c|}
$\begin{array}{c}\text { Internet } \\
\text { Disclosure } \\
\text { Index }\end{array}$ \\
.005 \\
\end{tabular}} \\
\hline Kendall's tau_b & & Correlation Coefficient & & & & & & & \\
\hline & \multirow[t]{2}{*}{ Volume } & Sig. $(2-$ tailed $)$ & . & .739 & .164 & .111 & .988 & .005 & .943 \\
\hline & & $\mathrm{N}$ & 101 & 101 & 101 & 101 & 101 & 101 & 101 \\
\hline & \multirow{3}{*}{ Medical } & Correlation Coefficient & -.028 & 1.000 & -.125 & .070 & -.068 & -.114 & $.207^{*}$ \\
\hline & & Sig. $(2-$ tailed $)$ & .739 & . & .201 & .383 & .419 & .161 & .013 \\
\hline & & $\mathrm{N}$ & 101 & 106 & 106 & 106 & 106 & 106 & 106 \\
\hline & \multirow{3}{*}{ IT } & Correlation Coefficient & .115 & -.125 & 1.000 & -.062 & -.063 & .049 & -.068 \\
\hline & & Sig. $(2-$ tailed $)$ & .164 & .201 & . & .436 & .450 & .549 & .420 \\
\hline & & $\mathrm{N}$ & 101 & 106 & 106 & 106 & 106 & 106 & 106 \\
\hline & \multirow{3}{*}{ Mcap (PLN) } & Correlation Coefficient & -.109 & .070 & -.062 & 1.000 & .036 & $-164^{*}$ & $.166^{*}$ \\
\hline & & Sig. $(2$ - tailed $)$ & .111 & .383 & .436 & . & .597 & .014 & .016 \\
\hline & & $\mathrm{N}$ & 101 & 106 & 106 & 106 & 106 & 106 & 106 \\
\hline & \multirow{3}{*}{ Age (KRS) } & Correlation Coefficient & -.001 & -.068 & -.063 & .036 & 1.000 & .113 & .024 \\
\hline & & Sig. $(2-$ tailed $)$ & .988 & .419 & .450 & .597 & . & .104 & .739 \\
\hline & & $\mathrm{N}$ & 101 & 106 & 106 & 106 & 106 & 106 & 106 \\
\hline & \multirow{3}{*}{ EPS (PLN) } & Correlation Coefficient & $-.195^{* *}$ & -.114 & .049 & $.164^{*}$ & .113 & 1.000 & .011 \\
\hline & & Sig. $(2-$ tailed $)$ & .005 & .161 & .549 & .014 & .104 & . & .880 \\
\hline & & $\mathrm{N}$ & 101 & 106 & 106 & 106 & 106 & 106 & 106 \\
\hline & \multirow{3}{*}{ Internet Disclosure Index } & Correlation Coefficient & .005 & $.207^{*}$ & -.068 & $.166^{*}$ & .024 & .011 & 1.000 \\
\hline & & Sig. $(2-$ tailed $)$ & .943 & .013 & .420 & .016 & .739 & .880 & . \\
\hline & & $\mathrm{N}$ & 101 & 106 & 106 & 106 & 106 & 106 & 106 \\
\hline
\end{tabular}




\begin{tabular}{|c|c|c|c|c|c|c|c|c|c|}
\hline \multirow[t]{21}{*}{ Spearman's rho } & \multirow{3}{*}{ Volume } & Correlation Coefficient & 1.000 & -.033 & .139 & -.164 & -.006 & $-.283^{* *}$ & .006 \\
\hline & & Sig. $(2-$ tailed $)$ & . & .740 & .165 & .102 & .953 & .004 & .952 \\
\hline & & $\mathrm{N}$ & 101 & 101 & 101 & 101 & 101 & 101 & 101 \\
\hline & \multirow{3}{*}{ Medical } & Correlation Coefficient & -.033 & 1.000 & -.125 & .085 & -.079 & -.137 & $.242^{*}$ \\
\hline & & Sig. $(2-$ tailed $)$ & .740 & . & .202 & .385 & .421 & .162 & .013 \\
\hline & & $\mathrm{N}$ & 101 & 106 & 106 & 106 & 106 & 106 & 106 \\
\hline & \multirow{3}{*}{ IT } & Correlation Coefficient & .139 & -.125 & 1.000 & -.076 & -.074 & .058 & -.079 \\
\hline & & Sig. $(2-$ tailed $)$ & .165 & .202 & . & .439 & .453 & .552 & .423 \\
\hline & & $\mathrm{N}$ & 101 & 106 & 106 & 106 & 106 & 106 & 106 \\
\hline & \multirow{3}{*}{ Mcap (PLN) } & Correlation Coefficient & -.164 & .085 & -.076 & 1.000 & .050 & $.219^{*}$ & $.230^{*}$ \\
\hline & & Sig. $(2-$ tailed $)$ & .102 & .385 & .439 & . & .613 & .024 & .018 \\
\hline & & $\mathrm{N}$ & 101 & 106 & 106 & 106 & 106 & 106 & 106 \\
\hline & \multirow{3}{*}{ Age (KRS) } & Correlation Coefficient & -.006 & -.079 & -.074 & .050 & 1.000 & .155 & .022 \\
\hline & & Sig. $(2-$ tailed $)$ & .953 & .421 & .453 & .613 & . & .112 & .822 \\
\hline & & $\mathrm{N}$ & 101 & 106 & 106 & 106 & 106 & 106 & 106 \\
\hline & \multirow{3}{*}{ EPS (PLN) } & Correlation Coefficient & $-.283^{* *}$ & -.137 & .058 & $.219^{*}$ & .155 & 1.000 & .018 \\
\hline & & Sig. $(2-$ tailed $)$ & .004 & .162 & .552 & .024 & .112 & . & .853 \\
\hline & & $\mathrm{N}$ & 101 & 106 & 106 & 106 & 106 & 106 & 106 \\
\hline & \multirow{3}{*}{ Internet Disclosure Index } & Correlation Coefficient & .006 & $.242^{*}$ & -.079 & $.230^{*}$ & .022 & .018 & 1.000 \\
\hline & & Sig. $(2-$ tailed $)$ & .952 & .013 & .423 & .018 & .822 & .853 & . \\
\hline & & $\mathrm{N}$ & 101 & 106 & 106 & 106 & 106 & 106 & 106 \\
\hline
\end{tabular}

Source: author's own work.

产 


\section{Appendix I}

Table 5. Sample details

\begin{tabular}{|c|c|c|c|c|}
\hline No. & Name & $\begin{array}{c}\text { Sector } \\
\text { standardized }\end{array}$ & Website address & IRI \\
\hline 1 & Baltic Ceramics Investments SA & Other & www.balticceramicsinvestments.com & 0.77 \\
\hline 2 & Site SA & IT & www.site.pl & 0.54 \\
\hline 3 & Partner Nieruchomosci SA & Other & www.partnernieruchomosci.com.pl & 0.46 \\
\hline 4 & Damf Inwestycje SA & IT & www.damfinwestycje.pl & 0.77 \\
\hline 5 & Fachowcy.pl Ventures SA & Other & www.fachowcy.pl & 0.85 \\
\hline 6 & Geotrekk SA & IT & www.geotrekk.pl & 0.69 \\
\hline 7 & Nowoczesna Firma SA & Other & www.nf.pl & 0.38 \\
\hline 8 & Momo SA & Chemicals & www.momo.com.pl & 0.31 \\
\hline 9 & Aztec International SA & Other & www.aztec-international.eu & 0.62 \\
\hline 10 & Boruta Zachem SA & Chemicals & www.boruta-zachem.pl & 0.85 \\
\hline 11 & K\&K Herbal Poland SA & Medical & www.kkpoland.pl & 0.92 \\
\hline 12 & Grupa HRC SA & HR & www.hrc.com.pl & 0.77 \\
\hline 13 & Medapp SA & IT & www.medapp.pl & 0.62 \\
\hline 14 & Farm 51 Group SA & Other & www.thefarm51.com & 0.62 \\
\hline 15 & Pixel Venture Capital SA & Finance & www.pixelvc.pl & 0.62 \\
\hline 16 & Macro Games SA & Other & www.macrogames.pl & 0.54 \\
\hline 17 & Milkpol SA & $\begin{array}{l}\text { Food, Beverages } \\
\& \text { Agriculture }\end{array}$ & www.milkpol.com.pl & 0.62 \\
\hline 18 & Teliani Valley Polska SA & $\begin{array}{l}\text { Food, Beverages } \\
\& \text { Agriculture }\end{array}$ & www.telianivalley.pl & 0.38 \\
\hline 19 & Suntech SA & IT & www.suntech.pl & 0.62 \\
\hline 20 & Rajdy 4x4 SA & Other & www.rajdy4x4-sa.pl & 0.23 \\
\hline 21 & QubicGames SA & Other & www.qubicgames.com & 0.85 \\
\hline 22 & Sferanet SA & IT & www.sferanet.pl & 0.85 \\
\hline 23 & Alumast SA & Other & www.alumast.eu & 0.69 \\
\hline 24 & Pharmena SA & Chemicals & www.pharmena.com.pl & 1 \\
\hline 25 & LS Tech Homes SA & Other & www.lstech-homes.com & 0.62 \\
\hline 26 & Astro SA & Other & www.astrosa.pl & 0.23 \\
\hline 27 & Eurosnack SA & $\begin{array}{l}\text { food, Beverages } \\
\& \text { Agriculture }\end{array}$ & www.eurosnack.pl & 0.85 \\
\hline 28 & Geotrans SA & Other & http://geotranssa.com.pl & 0.85 \\
\hline 29 & Aqua SA Bielsko-Biala & Other & www.aqua.com.pl & 0.92 \\
\hline 30 & Cloud Technologies SA & IT & www.cloudtechnologies.pl & 0.69 \\
\hline 31 & Agroliga Group PLC & $\begin{array}{l}\text { Food, Beverages } \\
\& \text { Agriculture }\end{array}$ & www.agroliga.com.ua & 0.54 \\
\hline 32 & Platige Image SA & Other & www.platige.com & 0.62 \\
\hline 33 & Orphee SA & Medical & www.orphee-medical.com & 0.46 \\
\hline 34 & JR Holding SA & Other & www.jrholding.pl & 0.92 \\
\hline
\end{tabular}


continued Table 5

\begin{tabular}{|c|c|c|c|c|}
\hline No. & Name & $\begin{array}{c}\text { Sector } \\
\text { standardized }\end{array}$ & Website address & IRI \\
\hline 35 & Letus Capital SA & Finance & http://letuscap.com & 0.46 \\
\hline 36 & Tech Invest Group SA & IT & www.tigsa.pl & 0.77 \\
\hline 37 & Copernicus Securities SA & Finance & www.copernicus.pl & 0.85 \\
\hline 38 & Fluid SA & Chemicals & www.fluid.pl & 0.85 \\
\hline 39 & Mennica Skarbowa SA & Finance & www.gmksa.pl & 0.85 \\
\hline 40 & Bit Evil SA & IT & www.bitevil.com & 0 \\
\hline 41 & Auxilia SA & Other & www.auxilia.pl & 0.85 \\
\hline 42 & Erne Ventures SA & Finance & http://www.erne.pl & 0.46 \\
\hline 43 & Eo Networks SA & IT & www.eo.pl & 0.85 \\
\hline 44 & Robinson Europe SA & Other & www.robinson.pl & 0.23 \\
\hline 45 & Genomed SA & Medical & www.genomed.pl & 0.92 \\
\hline 46 & Boomerang SA & Other & www.boomerang.com.pl & 0.15 \\
\hline 47 & Ekopol Górnośląski Holding SA & Chemicals & www.eg.com.pl & 0.62 \\
\hline 48 & Automatyka Pomiary Sterowanie SA & Other & www.aps.pl & 0.62 \\
\hline 49 & NWAI Dom Maklerski SA & Finance & www.nwai.pl & 0.85 \\
\hline 50 & Star Fitness SA & Other & www.star-fitness.pl & 0.38 \\
\hline 51 & Onico SA & Chemicals & www.onico.pl & 0.54 \\
\hline 52 & Europejski Fundusz Energii SA & IT & www.efesa.pl & 0.62 \\
\hline 53 & e-Kiosk SA & Other & www.e-kiosk.pl & 0.62 \\
\hline 54 & Eskimos SA & $\begin{array}{l}\text { Food, Beverages } \\
\text { \& Agriculture }\end{array}$ & www.eskimossa.pl & 0.62 \\
\hline 55 & M Trans SA & Other & www.mtrans.co & 0.62 \\
\hline 56 & EBC Solicitors SA & Finance & www.ebcsolicitors.pl & 0.77 \\
\hline 57 & ATC Cargo SA & Other & www.atc-cargo.pl & 0.92 \\
\hline 58 & Stem Cells Spin SA & Medical & www.stemcellsspin.com.pl & 0.77 \\
\hline 59 & Mera SA & Other & www.mera.pl & 0.54 \\
\hline 60 & Uhy Eca SA & Finance & www.ecagroup.pl & 0.77 \\
\hline 61 & e-Muzyka SA & Other & www.e-muzyka.pl & 0.69 \\
\hline 62 & Korbank SA & IT & www.korbank.pl & 0.31 \\
\hline 63 & Perma Fix Medical SA & Medical & www.medical-isotope.com & 1 \\
\hline 64 & Beskidzkie Biuro Consultingowe SA & Other & www.bbc-polska.com & 0.85 \\
\hline 65 & Merit Invest SA & Finance & www.meritinvest.pl & 0.77 \\
\hline 66 & Presto SA & Other & www.presto-kominy.pl & 0.69 \\
\hline 67 & Dom Lekarski SA & Medical & www.domlekarski.pl & 0.77 \\
\hline 68 & Auto Spa SA & Other & www.auto-spa.eu & 0.85 \\
\hline 69 & G Energy SA & Other & www.genergy.pl & 1 \\
\hline 70 & Inbook SA & Other & www.inbook.com.pl & 0.62 \\
\hline 71 & ArtP Capital SA & Other & www.artpcapital.pl & 0.69 \\
\hline 72 & 01Cyberaton SA & Other & www.01cyberaton.eu & 0.62 \\
\hline
\end{tabular}

Wydział Zarządzania UW DOI 10.7172/1733-9758.2018.27.9 
continued Table 5

\begin{tabular}{|c|c|c|c|c|}
\hline No. & Name & $\begin{array}{c}\text { Sector } \\
\text { standardized }\end{array}$ & Website address & IRI \\
\hline 73 & Verbicom SA & IT & www.verbicom.pl & 0.46 \\
\hline 74 & Grupa Emmerson SA & Other & www.grupaemmerson.pl & 0.62 \\
\hline 75 & InteliWISE SA & IT & www.inteliwise.pl & 0.62 \\
\hline 76 & Szar SA & Other & www.szar.pl & 0.31 \\
\hline 77 & Bras SA & Other & www.inventi-power.pl & 0.77 \\
\hline 78 & Softblue SA & IT & www.softblue.pl & 1 \\
\hline 79 & Kancelaria Prawna Inkaso WEC SA & Other & www.kancelariawec.eu & 0.92 \\
\hline 80 & Present24 SA & Other & www.present24sa.pl & 0.46 \\
\hline 81 & Acrebit SA & IT & www.acrebit.pl & 0.31 \\
\hline 82 & $\begin{array}{l}\text { Dolnoslaskie Centrum Developerskie } \\
\text { SA }\end{array}$ & Other & www.dcdsa.pl & 0.77 \\
\hline 83 & $\begin{array}{l}\text { Przedsiebiorstwo Telekomunikacyjne } \\
\text { Telgam SA }\end{array}$ & IT & www.telgam.pl & 0.15 \\
\hline 84 & Infoscan SA & Medical & www.infoscan.pl & 0.85 \\
\hline 85 & GLG Pharma SA & Medical & www.glgpharma.pl & 0.77 \\
\hline 86 & Prymus SA & Chemicals & www.prymussa.pl & 0.92 \\
\hline 87 & Photon Energy NV & Other & www.photonenergy.com & 0.69 \\
\hline 88 & Internity SA & Other & www.internitysa.pl & 0.54 \\
\hline 89 & Caspar Asset Management SA & Finance & www.caspar.com.pl & 0.69 \\
\hline 90 & Lauren Peso Polska SA & Other & www.laurenpeso.pl & 0.38 \\
\hline 91 & Grempco SA & Finance & www.grempco.com & 0.38 \\
\hline 92 & Rotopino.pl SA & Other & www.rotopino.pl & 0.46 \\
\hline 93 & Logintrade SA & Other & www.logintrade.pl & 0.69 \\
\hline 94 & Advertigo SA & Other & www.advertigo.pl & 0.15 \\
\hline 95 & Aqua SA & Other & www.aqua.poznan.pl & 0.62 \\
\hline 96 & Investeko SA & Other & www.investeko.pl & 0.54 \\
\hline 97 & Centrum Finansowe Banku BPS SA & Finance & www.cfbps.pl & 0.54 \\
\hline 98 & Ekobox SA & Other & www.ekobox.pl & 0.23 \\
\hline 99 & Agromep SA & Other & www.agromep.pl & 0.62 \\
\hline 100 & Analizy Online SA & Finance & www.analizy.pl & 0.69 \\
\hline 101 & Kofama Kozle SA & Other & www.kofama.pl & 0.54 \\
\hline 102 & Hurtimex SA & Other & www.hurtimex.com.pl & 0.46 \\
\hline 103 & Ackerman SA & Other & www.ackerman.pl & 0.46 \\
\hline 104 & $\begin{array}{l}\text { Wodkan Przedsiebiorstwo } \\
\text { Wodociagow i Kanalizacji SA }\end{array}$ & $\begin{array}{l}\text { Food, Beverages } \\
\& \text { Agriculture }\end{array}$ & www.wodkan.com.pl & 0.69 \\
\hline 105 & Notoria Serwis SA & Finance & www.notoria.pl & 0.38 \\
\hline 106 & 5th Avenue Holding SA & Other & www.5avenueholding.com & 0.85 \\
\hline
\end{tabular}

Source: author's own work. 


\section{References}

Alali, F. \& Romero, S. (2012). The use of the Internet for corporate reporting in the Mercosur (Southern common market): The Argentina case. Advances in Accounting, 28(1), 157-167.

Appiah, K.O., Amankwah, M.A., Adu Asamoah, L., \& Adu Asamoah, L. (2016). Online corporate social responsibility communication: An emerging country's perspective. Journal of Communication Management, 20(4), 396-411.

Arrow, K. (1971). The theory of risk aversion. Essays in the theory of risk-bearing. Chicago: Markham.

Biswas, P.K. \& Bala, S.K. (2015). General investors' views of information sources in Bangladesh. International Journal of Disclosure and Governance, 12(4), 284-299.

Czajor, P. \& Michalak, J. (2011). Voluntary disclosure of financial information on the Internet. Shareholders information needs and practice of largest companies in Poland. EEA Congress, Rome.

Diamond, D. W. \& Verrecchia, R. E. (1991). Disclosure, liquidity, and the cost of capital. The Journal of Finance, 46(4), 1325-1359.

Dunne, T., Helliar, C., Lymer, A., \& Mousa, R. (2013). Stakeholder engagement in internet financial reporting: The diffusion of XBRL in the UK The British Accounting Review, 45(3), 167-182.

Dyczkowska, J. (2014). Assessment of the quality of Internet financial disclosures using a scoring system. A case of Polish stock issuers. Journal of Accounting and Management Information Systems, 13(1), 50-81.

Ghasempour, A. \& MdYusof M.A. (2014). The effect of fundamental determination on voluntary disclosure of financial and nonfinancial information: The case of Internet reporting on the Tehran Stock Exchange. Journal of Accounting \& Marketing $3(2)$.

Gowthorpe, C. \& Flynn, G. (1997). Reporting on the web: State of the art. Accountancy: International Edition, 120(1248), 58-9.

Hanafi, S.R.B.M., Kasim, M.A.B., Ibrahim, M.K.B., \& Hancock, D.R. (2009). Business reporting on the internet: development of a disclosure quality index. International Journal of Business and Economics, 8(1).

Hussey, R. \& Sowinska, M. (1999). The risks of financial reports on the Internet. Accounting and Business, 18-19.

Kelton, A.S. (2012). Internet financial reporting: The effects of information presentation format and content differences on investor decision making. Computers in Human Behavior, 28(4), 1178-1185.

Khalil, A. \& Maghraby, M. (2017). The determinants of internet risk disclosure: empirical study of Egyptian listed companies. Managerial Auditing Journal, 32(8), 746-767.

Marston, C. \& Polei, A. (2004). Corporate reporting on the Internet by German companies. International Journal of Accounting Information Systems, 5(3), 285-311.

New Connect Issuers Code of Good Practice. (2010). Retrieved from https://newconnect.pl/pub/NEWCONNECT/dobre_praktyki/Zalacznik_Nr_1_ dobre_praktyki.pdf

Orens, R., Aerts, W., \& Cormier, D. (2010). Webbased non-financial disclosure and cost of finance. Journal of Business Finance \& Accounting, 37(9-10), 1057-1093.

Samaha, K., Dahawy, K., Abdel-Meguid, A., \& Abdallah, S. (2012). Propensity and comprehensiveness of corporate internet reporting in Egypt: Do board composition and ownership structure matter? International Journal of Accounting \& Information Management, 20(2), 142-170.

Spence, M. (1973). Job market signaling. The Ouarterly Journal of Economics, 87(3), 355-374.

Suchman, M. (1995). Managing legitimacy and institutional approaches. Academy of Management Review, 20(3), 571-610.

Uyar, A. (2011). Determinants of corporate reporting on the internet: An analysis of companies listed on the Istanbul Stock Exchange (ISE). Managerial Auditing Journal, 27(1), 87-104.

Xiao, J.Z., Yang, H., \& Chow, C.W. (2004). The determinants and characteristics of voluntary Internet-based disclosures by listed Chinese companies. Journal of Accounting and Public Policy, 23(3), 191-225. 